\title{
Corrigendum
}

Cold Spring Harb Protoc 2018; doi: 10.1101/pdb.prot097253

\section{Corrigendum: Lineage Tracing and Fate Mapping in Xenopus Embryos}

Sally A. Moody

In earlier versions of this protocol, the chemical names for the formulas $\mathrm{Na}_{2} \mathrm{HPO}_{4}$ and $\mathrm{NaH}_{2} \mathrm{PO}_{4}$ were inadvertently reversed: $\mathrm{Na}_{2} \mathrm{HPO}_{4}$ should have been defined as the dibasic phosphate, and $\mathrm{NaH}_{2} \mathrm{PO}_{4}$ should have been defined as the monobasic phosphate. The HTML versions of the two recipes in which the error appeared, "Paraformaldehyde (4\% in PBS)" (doi: 10.1101/pdb.rec104588) and "Phosphate-Buffered Saline (PBS) (0.1 M, pH 7.4)" (doi: 10.1101/pdb.rec104604), have been corrected, as has the most recent PDF version of the protocol. Corrected versions of the recipes are also included below.

Paraformaldehyde (4\% in PBS)

1. Add $4 \mathrm{~g}$ of paraformaldehyde to a beaker containing $40 \mathrm{~mL}$ of distilled $\mathrm{H}_{2} \mathrm{O}$. Cover with foil and heat to $60^{\circ} \mathrm{C}$ in a chemical fume hood with constant stirring. Do not let the temperature rise above $65^{\circ} \mathrm{C}$.

2. Add $1 \mathrm{~N} \mathrm{NaOH}$ drop-wise, while stirring, until the solution just clears. Cool the solution on ice to room temperature.

3. Add $0.9 \mathrm{~g}$ of $\mathrm{NaCl}$ and stir until dissolved.

4. Add $40 \mathrm{~mL}$ of $0.2 \mathrm{M}$ dibasic $\left(\mathrm{Na}_{2} \mathrm{HPO}_{4}\right)$ phosphate buffer (PB) stock (pH 7.4) and $10 \mathrm{~mL}$ of monobasic $\left(\mathrm{NaH}_{2} \mathrm{PO}_{4}\right) \mathrm{PB}$ stock $(\mathrm{pH} 7.4)$.

Prepared PB stocks can be stored at room temperature for months.

5. Bring the volume to $100 \mathrm{~mL}$ with distilled $\mathrm{H}_{2} \mathrm{O}$.

6. Mix thoroughly and store in the refrigerator or freezer $\left(-20^{\circ} \mathrm{C}\right)$ in small, single-use aliquots for months.

Phosphate-Buffered Saline (PBS) (0.1 $\mathrm{M}, \mathrm{pH} 7.4)$

1. Mix $40 \mathrm{~mL}$ of $0.2 \mathrm{M}$ dibasic $\left(\mathrm{Na}_{2} \mathrm{HPO}_{4}\right)$ phosphate buffer (PB) stock with $10 \mathrm{~mL}$ of monobasic $\left(\mathrm{NaH}_{2} \mathrm{PO}_{4}\right)$ PB stock.

Prepared PB stocks can be stored at room temperature for months.

2. Add $0.9 \mathrm{~g} \mathrm{NaCl}$ and stir until dissolved.

3. Bring the volume to $100 \mathrm{~mL}$ with distilled $\mathrm{H}_{2} \mathrm{O}$ and adjust the $\mathrm{pH}$ to 7.4.

(C) 2021 Cold Spring Harbor Laboratory Press

Cite this corrigendum as Cold Spring Harb Protoc; doi:10.1101/pdb.corr107781 


\section{Corrigendum: Lineage Tracing and Fate Mapping in Xenopus Embryos}

Sally A. Moody

Cold Spring Harb Protoc; doi: 10.1101/pdb.corr107781

\begin{tabular}{cc}
$\begin{array}{r}\text { Email Alerting } \\
\text { Service }\end{array}$ & Receive free email alerts when new articles cite this article - click here. \\
\hline $\begin{array}{c}\text { Subject } \\
\text { Categories }\end{array}$ & Browse articles on similar topics from Cold Spring Harbor Protocols. \\
\hline
\end{tabular}

